Full-text Available Online at www.ajol.info and www.bioline.org.br/ja
J. Appl. Sci. Environ. Manage. March 2014

Vol. 18 (1) $55-60$

\title{
Impact Assessment and Bioremediation of oil Contaminated Soil: A Case Study of Koko and Ajoki Communities, Niger Delta Nigeria \\ *11MASUEN OI; GALASI, DT; OMOROGIEVA OM
}

\author{
${ }^{I}$ Department of Geology, University of Benin, Benin City \\ ${ }^{2}$ Department of Science Laboratory Technology, Faculty of Life Sciences \\ University of Benin, Benin City.
}

\begin{abstract}
KEYWORDS: Niger - Delta, Impact, Assessment, Remediation and Contaminated - Soils
ABSTRACT: The research was conducted in two notable oil producing communities in Niger Delta, South - South geopolitical zones of Nigeria with aim of assessing the impact and recommending a remediation technique for reclaiming the land for agricultural industrial, and residential purposes. The communities are; Ajoki Community in Ikpoba Okha Local Government Area of Edo State and Koko Community in Warri North Local Government Area of Delta State; both communities are located on $05^{0} 25^{\prime \prime} E$ and $6^{0} 05^{\prime \prime} N$. Eleven (11) soil samples were collected in and around the oil producing communities, five from each community and one from Ugbowo Community in Benin City as a control site. The soils were first tested to ascertain the level of contamination before the experimental procedure began. The physiochemical parameters were determined using standard chemical methods of soil determination while remediation process was descriptive using denitrifying bacteria for 27 days at 7 days intervals. The results obtained were subjected to statistical treatment using micro soft excel format, the results were presented in tables and in graphs for easy understanding and explanation. The geochemical results show that the pollution was mild while the remediation method adopted yielded a positive result which, however, reduced the soil organic content, total nitrogen, nitrate and phosphorus. @ JASEM
\end{abstract}

\section{http://dx.doi.org/10.4314/jasem.v18i1.8}

\section{Introduction:}

Since the commercial exploration of petroleum (hydrocarbon) started in Nigeria in 1958 in Oloibiri in the present day Bayelsa State in South - South geopolitical zone of Nigeria, the so-called "blackgold" has continuously grown to be the mainstay of the country's economy. Exploration of hydrocarbon which has its advantage as the mainstay of the country's economy has also been identified as one of the major environmental pollutants in the Niger - Delta region of the country, Odu (1972), Imasuen and Omorogieva (2013), Browning (1969), Raymond and Okieimen (2000), Ezemonye (2013). This is as a result of oil spillage and gas flaring; the resulting effects of these activities lead to environmental degradation, soil depletion, water contamination and atmospheric pollution which have adversely affected the inhabitants and the communities where such activities are carried out. Civil unrest against environmental degradation has also been witnessed in the Niger - Delta, Njoku et. al., (2009).

\footnotetext{
*Correspondence email: isaacokpes@yahoo.com
}

The effects of oil contamination on the environment, especially on soil quality has been one of the major concerns in Nigeria and regulatory bodies universally. Soil quality determines its actual and potential use. For example, the quality of soil intended for agricultural use depends on the concentration of heavy metals in it, Ukpebor and Unuigbe (2003); Osibanjo et. al., (1983) reported that Nigerian crude oil has a high concentration of iron, copper, zinc, lead and mercury Harrison (1983) indicated that heavy metals can become a threat to vegetation and animals and ultimately affects the quality of human life.

In a recent research investigation, Imasuen and Omorogieva (2013a), reported that food crops grown around contaminated sites like mechanic workshop, refuse dumpsite and waste currency dumpsite with particular emphasis on cassava and plantain were highly contaminated with heavy metals, thereby exposing the animals and humans that consume it to health risk. 
It becomes imperative that soils contaminated with foreign and dangerous materials introduced by natural and/or anthropogenic means such as earthquake, volcanic eruption, weathering processes, gas flaring, and oil spillage, industrial activities etc should be subjected to thorough remediation for the purposes of agriculture, residential and commercial activities. The significance of this research is to introduce denitrifying bacteria as a method of bioremediation in soils polluted with petroleum/crude oil and the impact of such soil in the ecological system as a whole. Figure (1) below shows the map of the study area.

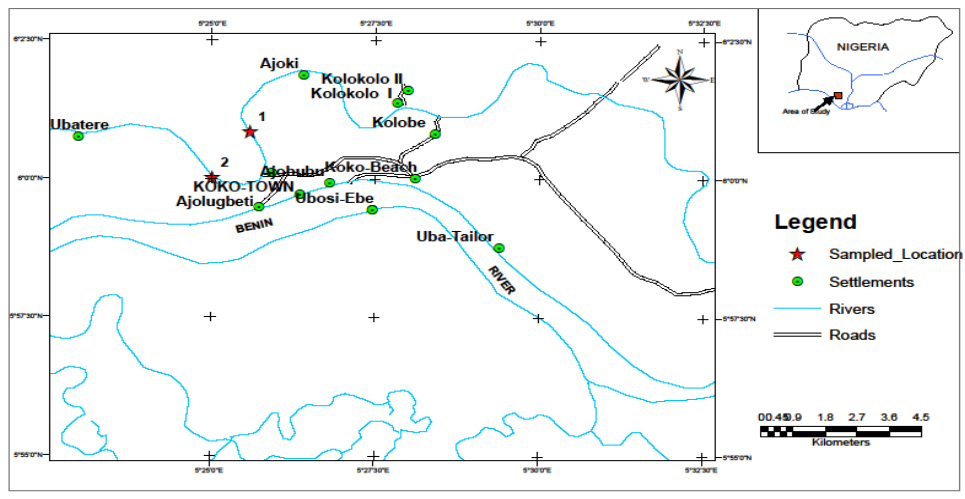

FIG. 1: MAP OF STUDY AREA SHOWING THE SAMPLED STATION ALONG BENIN RIVER

MATERIALS AND METHODOLOGY

The area of study falls within Ajoki Community in Ikpoba - Okha Local Government Area in Edo State on coordinate $06^{\circ} 05^{\prime \prime} N$ and $05^{\circ} 25^{\prime \prime} E$. It is located at the border between Edo and Delta States; Ajoki is an Itsekiri speaking community with traces of Ijaw and other ethnic groups. It is rich in hydrocarbon and therefore a host to major oil exploration companies such as Nigeria Petroleum Development Company (NPDC) amongst others.

On the other hand, Koko is located in Warri-North Local Government Area of Delta State, and on coordinate $06^{\circ} 00^{\prime \prime} N$ and $05^{\circ} 25^{\prime \prime} E$. Literature has it that Koko was the first community in Nigeria in which toxic waste was deposited in pretence of construction materials by an Italian business man in 1987. This transboundary toxic waste brought to fore the consciousness of environmental monitoring and management in Nigeria as a nation. Figure (1) above shows the sampled area.

The materials used in this research include the following; contaminated soil from site, soil from non contaminated site, spatula, $250 \mathrm{ml}$ conical flask, $50 \mathrm{ml}$ burette, $10 \mathrm{ml}$ pipette, concentrated hydrogen tetraoxosulphate (IV) acid, phosphoric acid, N-potassium dichromate, Diphenylamine, Atomic Absorption Spectrometer (AAS), Standard
$\mathrm{NO}_{3}, \mathrm{KCN}$, Ammonia, $\mathrm{NaS}, \mathrm{Pb}$ standard stock e.t.c.

The petroleum sheen test was carried out prior to sampling. This is a quick and easy field method that can be used to determine if soil sample is considered petroleum saturated. After the preliminary test, at least one foot of the exposed soil was removed before the collection of the sample; this is to ensure the collection of fresh soil sample. The soil samples were collected with hand auger and trowel at a depth of $0-5 \mathrm{~cm}$ and then wrapped in a well labeled foil paper to avoid alteration of physical and chemical properties and then taken to the laboratory for analysis. Eleven (11) samples, five from each community and one from control site at Ugbowo main campus of the University of Benin were collected. The soils were air dried for several days after which they were then grounded in an agate mortar and sieved through $2 \mathrm{~mm}$ nylon sieve. The treated soil samples were digested and analysed using standard chemical method of soil determination after Walkely and Black (1934). The results obtained were further subjected to statistical treatment using micro soft Excell (2007) version; the results were then presented in graphs and tables for easy understanding.

\section{RESULTS AND DISCUSSION}

At the commencement of experiment, the soil $\mathrm{pH}$ was measured to be 5.69 indicating acidic soil. The acidic nature is due to heavy rainfall which leached 
the major basic cations such as $\mathrm{N}_{\mathrm{a}}^{+}, \mathrm{Mg}^{2+}, \mathrm{K}^{+}$and $\mathrm{Ca}^{2+}$. As shown in table (1), the control soil sample $\mathrm{pH}$ was found to be 8.27 which is about 31.2 percent difference in value from the contaminated soil. This result revealed that petroleum contaminated soil has increased in $\mathrm{pH}$ against the natural background. The soil organic content was low in value, about 1.33 percent, however, when the soil was contaminated with, petroleum, the organic content was further reduced to 1.30 percent which is 3.99 percentage reduction indicating that soil contaminated with petroleum reduces soil fertility. Table (1) also shows that of all the exchangeable cations, sodium $\left(\mathrm{N}_{\mathrm{a}}^{+}\right)$was the most abundant with 285 percentage increase in value from non contaminated soil to contaminated soil $(0.2-0.77)$. Others include potassium $\left(\mathrm{K}^{+}\right) 283.33$ percent $(0.12-0.46)$, magnesium $\left(\mathrm{Mg}^{2+}\right) 283.33$ percent $(0.06-0.23)$. There is also increase in the heavy metals concentration of the contaminated site as compared to the non-contaminated site. For example, $\mathrm{Fe}^{3+}$ increased by 75 percent (2.41 $4.22), \mathrm{Zn}^{2+}$ increased by 76.9 percent $(0.39-0.69)$, $\mathrm{Mn}^{2+}$ increased by 76.3 percent $(0.59-1.04), \mathrm{Cu}^{2+}$ increased by 76.9 percent $(0.39-0.69)$ and $\mathrm{Pb}^{2+}$ increased by 85.7 percent $(0.07-0.13)$. Although the concentrations are relatively low and falls within the range of normal soil; they are present in organometallic compounds that migrate with hydrocarbon thereby acting as effective catalysts for the formation of hydrocarbon. They promote the formation of petroleum from organic remains; Odu (1978). This could be the reason why Nigerian crude oil is rich in some heavy metals; Osibanjo et al., (1983) reported that Nigerian crude oil is rich in heavy metals. It is imperative to mention that the increase in heavy metal concentration as components of petroleum, affects the organic carbon, total nitrogen, nitrate, ammonium and exchangeable cations in the soil. It is also responsible for the stoppage of the microbial activities of micro-organisms, mineralization and humification of organic matter.

Table (2) shows the remediation process; the experiment was set up and closely monitored for a period of twenty seven (27) days at seven (7) days intervals. After twenty seven (27) days, it was observed that the bacterial (bioremediation) has affected the physico-chemical parameters. The soil $\mathrm{pH}$ increased from 5.69 before the start to 6.43 after twenty seven (27) days, an increment of thirteen (13) percent. The heavy metal content of the soil was also reduced. However, the organic content, total nitrogen and phosphorus content were drastically reduced; this can be attributed to the nature of the remediating agent. The result shows that it consumes organic matter while remediating; this is a denitrifying bacteria as it was identified in this study to aligne with Abioye et. al., (2009). Soil contaminated with petroleum reduced soil fertility for agricultural produce, toxic substance introduced to the soil around contaminated sites and elsewhere were absorbed by crops cultivated around the sites, Amusan et. al., (2005), Imasuen and Omorogieva (2013a). These toxic substances such as heavy metals are consumed by man through the food chain consequently affect the quality of human life; Harrison (1982). It can also lead to Ozone layer depletion, environmental degradation and serious threat to aquatic life.

Table 1: Summary of Results

\begin{tabular}{cclllll}
\hline \multicolumn{7}{c}{ Table 1: Summary of Results } \\
\hline PARAMETERS & UNITS & MEAN 1 & MEAN 7 & MEAN 14 & MEAN 27 & S12 \\
& & & & & & MEAN \\
\hline $\mathrm{Ph}$ & & 5.692727 & 5.87 & 6.0463636 & 6.4345455 & 8.2675 \\
$\mathrm{EC}$ & $\mathrm{uS} / \mathrm{cm}$ & 384 & 349.3636 & 309.45455 & 218.72727 & 97.25 \\
$\mathrm{TDS}$ & $\mathrm{mg} / \mathrm{I}$ & 192 & 174.6818 & 154.72727 & 109.36364 & 46.575 \\
$\mathrm{Cl}$ & $\mathrm{mg} / \mathrm{I}$ & 115.2 & 104.8091 & 92.836364 & 65.618182 & 26.5 \\
$\mathrm{SO}_{4}{ }^{2-}$ & $\mathrm{mg} / \mathrm{I}$ & 34.94455 & 31.79273 & 28.12 & 19.904545 & 9.0025 \\
$\mathrm{NO}_{3}{ }^{-}$ & $\mathrm{mg} / \mathrm{I}$ & 23.80818 & 21.66091 & 19.185455 & 13.561818 & 5.8475 \\
$\mathrm{PO}_{4}{ }^{3-}$ & $\mathrm{mg} / \mathrm{I}$ & 7.296364 & 6.640909 & 5.8809091 & 4.1572727 & 1.875 \\
$\mathrm{Na}^{+}$ & $\mathrm{meq} / 100 \mathrm{~g}$ & 0.768182 & 0.699091 & 0.6181818 & 0.4381818 & 0.2 \\
$\mathrm{~K}^{+}$ & $\mathrm{meq} / 100 \mathrm{~g}$ & 0.461818 & 0.418182 & 0.3709091 & 0.2627273 & 0.12 \\
$\mathrm{Ca}^{2+}$ & $\mathrm{meq} / 100 \mathrm{~g}$ & 0.115455 & 0.104545 & 0.0927273 & 0.0663636 & 0.03 \\
$\mathrm{Mg}^{2+}$ & $\mathrm{meq} / 100 \mathrm{~g}$ & 0.23 & 0.210909 & 0.1854545 & 0.1318182 & 0.06 \\
$\mathrm{Exc} \mathrm{Base}^{2+}$ & $\mathrm{meq} / 100 \mathrm{~g}$ & 1.574545 & 1.431818 & 1.2681818 & 0.8881818 & 0.41 \\
$\mathrm{E} . \mathrm{Acidity}^{3+}$ & $\mathrm{meq} / 100 \mathrm{~g}$ & 0.144545 & 0.137273 & 0.1336364 & 0.1254545 & 0.06 \\
$\mathrm{Fe}^{3+}$ & $\mathrm{mg} / \mathrm{I}$ & 4.224545 & 3.91 & 3.4036364 & 2.4063636 & 1.09 \\
$\mathrm{Zn}^{2+}$ & $\mathrm{mg} / \mathrm{I}$ & 0.690909 & 0.628182 & 0.5563636 & 0.3945455 & 0.18 \\
$\mathrm{Mn}^{2+}$ & $\mathrm{mg} / \mathrm{I}$ & 1.035455 & 0.943636 & 0.8354545 & 0.5909091 & 0.27 \\
$\mathrm{Cu}^{2+}$ & $\mathrm{mg} / \mathrm{I}$ & 0.690909 & 0.628182 & 0.5563636 & 0.3945455 & 0.18 \\
$\mathrm{Ni}^{2+}$ & $\mathrm{mg} / \mathrm{I}$ & 1.535455 & 1.399091 & 1.2390909 & 0.8745455 & 0.4 \\
$\mathrm{Cd}^{2+}$ & $\mathrm{mg} / \mathrm{I}$ & 0.04 & 0.034545 & 0.03 & 0.0209091 & 0.01 \\
$\mathrm{~V}^{2+}$ & $\mathrm{mg} / \mathrm{I}$ & 0.115455 & 0.104545 & 0.0927273 & 0.0663636 & 0.03 \\
$\mathrm{Cr}^{6+}$ & $\mathrm{mg} / \mathrm{I}$ & 0.084545 & 0.075455 & 0.0681818 & 0.0481818 & 0.02 \\
$\mathrm{~Pb}^{2+}$ & $\mathrm{mg} / \mathrm{I}$ & 0.127273 & 0.114545 & 0.1018182 & 0.0718182 & 0.03 \\
$\mathrm{Hg}$ & $\mathrm{mg} / \mathrm{I}$ & $\mathrm{ND}$ & $\mathrm{ND}$ & $\mathrm{ND}$ & $\mathrm{ND}$ & $\mathrm{ND}$ \\
$\mathrm{As}$ & $\mathrm{mg} / \mathrm{I}$ & 0.095 & 0.085 & 0.075 & 0.055 & $\mathrm{ND}$ \\
$\mathrm{Org}^{2+} \mathrm{C}$ & $\%$ & 1.295455 & 1.123636 & 0.9081818 & 0.6890909 & $\mathbf{1 . 3 3}$ \\
$\mathrm{T}^{\mathrm{N}} \mathrm{\%}$ & $\mathbf{\%}$ & 0.129091 & 0.113636 & 0.09 & 0.0681818 & $\mathbf{0 . 1 3}$ \\
\hline & & & & & &
\end{tabular}


Table 2: Forecasting Based On Observed Trends

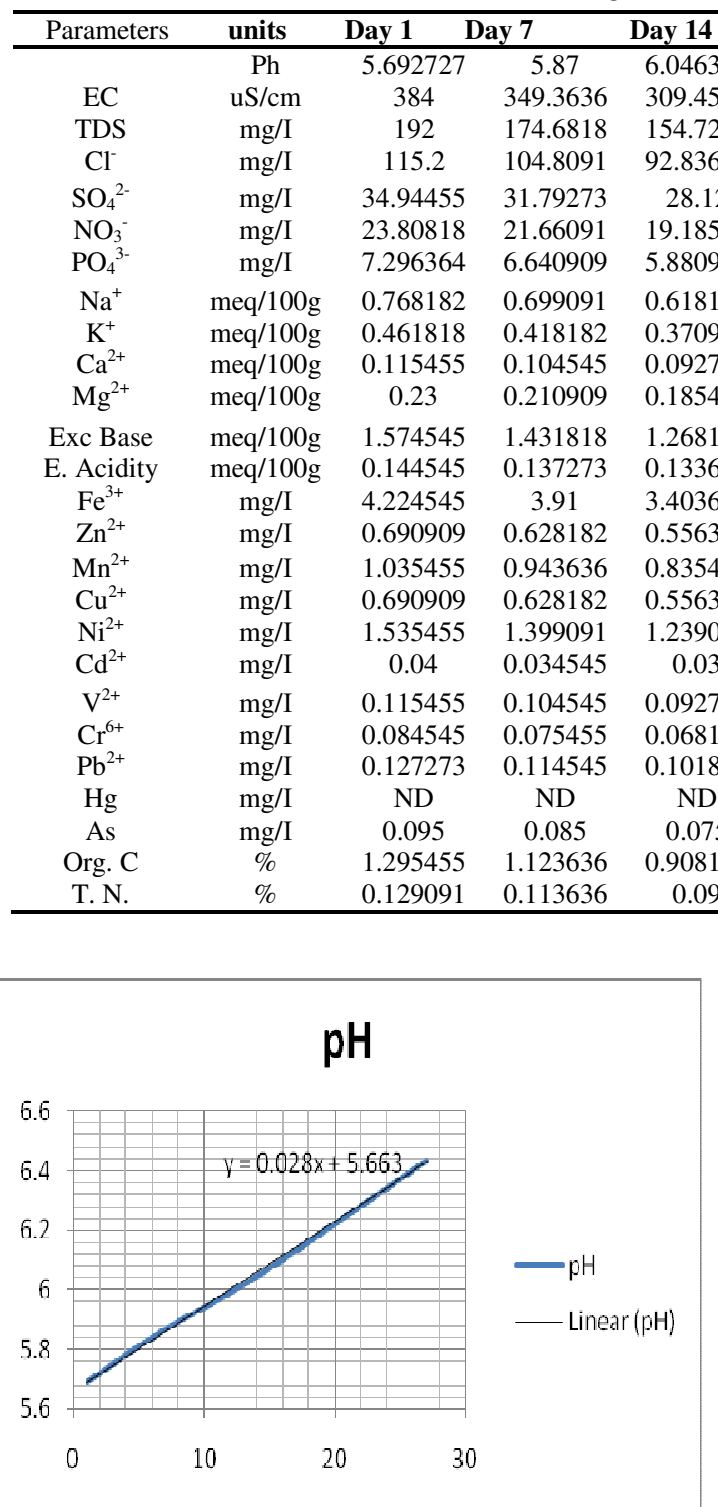

Fig 2: Trend of Action of Bacteria on $\mathrm{Ph}$

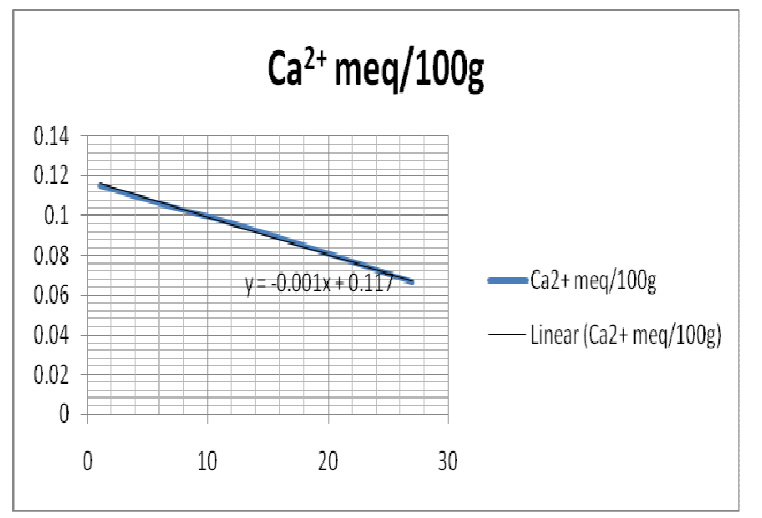

Fig 3:Trend of Action of Bacteria on calcium Content

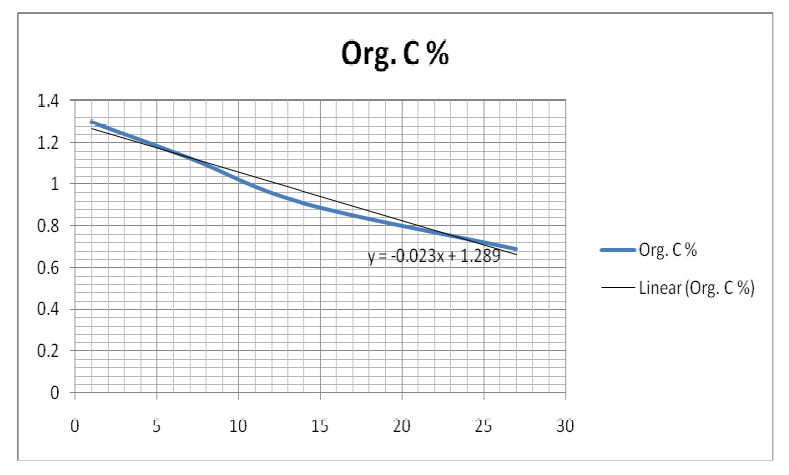

Fig: 4: Effect of Bacteria on Soil Organic Content 
Summary: Eleven (11) soil samples were collected from the field, five (5) from Ajoki, five (5) from Koko and one (1) from Ugbowo Campus of the University of Benin as a control sample. The soils were subjected to petroleum sheen test in order to determine whether the soil is saturated with petroleum before taking to the laboratory for analysis using standard chemical method for soil determination after Walkley and Black (1934). The results were subjected to statistical treatment and presented in the mean form in table (1). The results obtained shows that the soil was mildly polluted. Table (2) shows the remediation process by denitrifying bacteria. During the remediation process for a period of 27 days, it was observed that $\mathrm{pH}$ of the soil increased from 5.69 to 6.43 , the heavy metals gradually reduced from day one towards day twenty seven. In the same vein, the exchangeable cations also decreased in values as the remediation process advanced; this indicates that the remediation method was effective. However, the soil organic content, phosphorus and total nitrogen content as well as the ammonium tend towards a negative value indicating that the remediation process chosen has no restoration effect on the soil parameters as the remediating agent consume it in the process of remediation. Hence the bacteria were identified as denitrifying. The experiment also shows that remediation process does not improve calcium to magnesium ratio of the soil as it stands fairly constant at 0.5 on both the treated and controlled soil. This also means that it will be more difficult for plants to take up potassium and there can be problems with soil structure breaking down due to dispersion, the (preferred) level for this purpose is at least 3.

A maximum of one hundred and seventeen (117) days exchangeable acidity was observed and a minimum of fourty two (42) days for cadmium, following the $\mathrm{pH}$ trends, an approximate number of thirty (30) days will be required to achieve the expected range of $86.0-6.5$ for agricultural soil, Table (2). While appreciating the reduction in heavy metals, reduction in soil acidity and increase in exchangeable base cations, were suggested by Imasuen (1987), Imasuen and Onyeobi (2013) for improving agricultural soil in addition to organic manure.

Acknowledgement: The authors will like to acknowledge the inhabitants of Ajoki and Koko Communities for their cooperation and assistance during the field work and soil sampling.

\section{REFERENCES}

Abioye, O. P., Alonge, O. A., and Ijah, U. J. J., 2009. Biodegradation of Crude Oil in Soil Amended with Melon Shell. AU J.T. 13(1): pp 34- 38

Amusan A.A. Ige D.V; and Olawale R. (2005):Characteristics of soils and Crops, Uptake of Metals in Municipal Waste Dumpsite in Nigeria. J. Hum.Ecol;17(3): 167171

Browning, E. M., (1969): Toxicity of Industrial Metals. 2nd Edition. Butterworth, London.

Ezemonye, L.I.N. (2013): Ecotoxicological Assurance of Environmental Integrity: Policing the Pollutants. Inaugural lecture series 129, University of Benin, Benin city, Nigeria.

Harrison, R. M. (1982): Pollution, Causes, Effects and Control ( $1^{\text {st }}$ edn.). London:The Royal Society of Chemistry.

Imasuen O.I and Onyeobi T.U.S. (2013): Chemical Composition of soils in Part of Edo State South Western Nigeria and their Relationship to Soil Productivity. J.Appl. Sci \& Environ. Manage. Vol 17 (3) p379-386

Imasuen, O. I. (1987): Kaolin-Smectite Transformations and Soils of Mid western Nigeria, Unpublished Ph.D Thesis, the University of Western Ontario, Canada, 329p.

Imasuen, O.I and Omorogieva, O.M. (2013): Comparative Study of Heavy Metals Distribution in Mechanic Workshop and Refuse Dumpsite in Oluku and Otofure, Edo, South-Western Nigeria. J .Appl. Sci. Environ .Manage. 3 (17) p425-430. $\underline{w w w . a j o l . i n f o}$ and $\underline{w w w . b i o l i n e . o r g . b r / j a}$

Imasuen, O.I and Omorogieva, O.M. (2013a): Sources and Environmental Implication of Heavy Metal Pollution in Plants Grown Around Contaminated Site in Edo State, Nigeria. Resource Journal in Engineering and Applied Sciences: USA, 2(5) 385-391. www.emergingresources.org

Njoku, K. L., Akinola, M. O., and Oboh, B. O., (2009). Phytoremediation of Crude Oil Contaminated Soil: The Effect of Growth of Glycine Max on the Physio - Chemistry and 
Crude Oil Contents of Soil. Nature and Science; 7(10): pp $79-85$

Odu, C. T. I., 1978. Fermentation, Characteristic and Biochemical Reactions of Organisms Isolated from Oil Polluted Soils. Environmental Pollution, University of Ibadan, Nigeria, 15: pp $271-276$

Odu, C. T., 1972. Microbiology of Soil Contaminated with Petroleum Hydrocarbon. J. Environ Microbiol; 59: pp 201 - 208

Osibanjo, O.. * Kakulu, S. E. and Ajayi, S. O. (1983): Atomic Absorption pectrophotometric Determination of Trace Metals in Nigerian Petroleum Using a Mixed-Solvent System. Analyst (London), Vol. 49, 127 â€" 129.
Raymond . W. and Okieimen F.E:(2000) Heavy Metals in Contaminated Soils: A Review of Sources, Chemistry, Risks and Best Available Strategies for Remediation. Available Online Via Google Search.

Ukpebor, E. E. and Onuigbe, C. A. (2003) Heavy Metals Concentration in the Subsoil of Refuse Dumpsite in Benin City, Nigeria. Ghana Journal of Sci. 43: pp 9-15

Walkley, A. and I.A. Black. (1934). An Examination of Degtjareff Method for Determining Soil Organic Matter and a Proposed Modification of the Chronic Acid Titration Method Soil Sci. 37p, 29 - 37. 